\title{
THE IMPACT OF TEACHER TRAINING ON STUDENT ACHIEVEMENT: QUASI-EXPERIMENTAL EVIDENCE FROM SCHOOL REFORM EFFORTS IN CHICAGO
}

\author{
Brian A. Jacob \\ Lars Lefgren \\ Working Paper 8916 \\ http://www.nber.org/papers/w8916 \\ NATIONAL BUREAU OF ECONOMIC RESEARCH \\ 1050 Massachusetts Avenue \\ Cambridge, MA 02138 \\ April 2002
}

We would like to thank the Consortium on Chicago School Research and the Chicago Public Schools for providing the data used in this study. We are grateful to Joshua Angrist, Mark Duggan, Michael Greenstone, Steven Levitt, Brigitte Madrian, and seminar participants at the University of Chicago and BYU for helpful suggestions. All remaining errors are our own. The views expressed herein are those of the authors and not necessarily those of the National Bureau of Economic Research.

(C) 2002 by Brian A. Jacob and Lars Lefgren. All rights reserved. Short sections of text, not to exceed two paragraphs, may be quoted without explicit permission provided that full credit, including $\odot$ notice, is given to the source. 
The Impact of Teacher Training on Student Achievement:

Quasi-Experimental Evidence from School Reform Efforts in Chicago

Brian A. Jacob and Lars Lefgren

NBER Working Paper No. 8916

April 2002

JEL No. I21, I28, J24

\begin{abstract}
While there is a substantial literature on the relationship between general teacher characteristics and student learning, school districts and states often rely on in-service teacher training as a part of school reform efforts. Recent school reform efforts in Chicago provide an opportunity to examine in-service training using a quasi-experimental research design. In this paper, we use a regression discontinuity strategy to estimate the effect of teacher training on the math and reading performance of elementary students. We find that marginal increases in-service training have no statistically or academically significant effect on either reading or math achievement, suggesting that modest investments in staff development may not be sufficient to increase the achievement of elementary school children in high poverty schools.
\end{abstract}

Brian A. Jacob

John F. Kennedy School of Government Harvard University

79 JFK Street

Cambridge, MA 02138

and NBER

617-384-7968

brian_jacob@harvard.edu
Lars Lefgren

Department of Economics

Brigham Young University

130 Faculty Office Building

Provo, UT 84602-2363

1-lefgren@byu.edu 


\section{Introduction}

There is a substantial literature on the relationship between teacher characteristics and student learning. Most prior research on this topic has focused on teachers' educational background, years of teaching experience and salaries. The results of this work are mixed. While it is clear that certain teachers are more effective than others at increasing student performance, there is considerably less consensus on whether specific, observable teacher characteristics such as education or experience produce higher performance. ${ }^{1}$

While most research has focused on general skills, school districts and states often rely on in-service staff development as a way to improve student learning. This on-the-job training seeks to instruct teachers in content as well as pedagogy. Professional development is an extremely widespread practice in U.S. Public Schools. Seventy-two percent of teachers report having engaged in training related to the subject area of their main teaching assignment during the previous 12 months (Parsad et. al. 2000). A similar fraction reports having received training on how to implement new teaching methods. Despite the widespread nature of these activities, the intensity of training is typically fairly low, with more than half of the teachers engaging in eight hours or less of training in each of these areas per year. Unfortunately, most of the existing research on in-service training suffers from the fact that the training is endogenously determined by teachers and schools.

\footnotetext{
${ }^{1}$ There is still considerable disagreement regarding the causal effect of educational expenditures on academic achievement. Hanushek (1996) asserts that there is little evidence that increased educational expenditures can systematically increase academic achievement. Hedges and Greenwald (1996) offer a different interpretation of the evidence, claiming that although many individual studies find no significant effect, the average effect estimate is positive. More recent experimental evidence suggests that at least one form of expenditure — reduced class sizedoes have a substantial effect on student achievement (Krueger 1999). Using a quasi-random research design,
} 
Recent school reforms in Chicago, however, provide an excellent opportunity to evaluate the causal impact of teacher training on student performance. In 1996, the Chicago Public School system (CPS) placed 71 of its 489 elementary schools on academic probation. These probation schools received special funding for staff development as well as technical assistance and enhanced monitoring. Eligibility for probation was determined on the basis of standardized reading scores - schools in which fewer than 15 percent of students scored at or above national norms in reading were subject to probation; those with 15 percent or more of students at national norms were not subject to probation. The existence of strict cutoffs created a highly non-linear relationship between a school's reading achievement in 1996 and the likelihood that the school was on probation in subsequent years. We exploit this discontinuity to identify the impact of teacher training on student achievement.

Note that this strategy does not identify the aggregate effect of the school probation policy since the accountability measures provided all low-achieving schools (both those who just missed and just made the cutoff) an incentive to increase student performance because such lowachieving schools that did not demonstrate improvement were subject to further sanctions. ${ }^{2}$ Rather, this strategy effectively identifies the impact of the resources provided to certain lowachieving schools under the probation policy. Because the technical assistance and monitoring resources provided to probation schools were quite small (see discussion below) and were designed primarily to enhance teacher classroom performance (and thus might be considered a component of teacher training), our discussion in this paper will focus on the impact of teacher

\footnotetext{
Guryan (2000) also finds that increases in school funding may have increased the performance of elementary school students in Massachusetts.

${ }^{2}$ Jacob (2002) finds evidence that the incentives provided by school probation, along with student-oriented accountability measures, led to a substantial increase in math and reading achievement.
} 
training with the understanding that it includes the effect of all of the resources provided to schools under the probation policy.

Utilizing exogenous variation in probation status caused by the discontinuity described above, we find that moderate increases in teacher training have no statistically or academically significant effect on either reading or math achievement. These results do not vary across race, gender, socio-economic background or student ability and are robust to a number of alternative specifications. Our results suggest that modest investments in staff development may not be sufficient to increase the achievement of elementary school children in high poverty schools.

The remainder of this paper is organized as follows. Section 2 reviews the literature on teacher training and provides background on the Chicago probation policy. Section 3 describes our data and Section 4 explains our empirical strategy. Section 5 presents findings on the effectiveness of in-service training. Section 6 explores the policy effects in more detail, examining the heterogeneity in effects across students and providing a series of robustness checks for our results. Section 7 discusses some of the implications of these findings and concludes.

\section{Background}

\section{A. Prior Literature}

Despite the importance of teacher training in most school districts, there is surprisingly little evidence on the effect of teacher training on student achievement. Indeed, as Angrist and Lavy (2001) pointed out, there seems to have been more research on the impact of teacher training in developing countries than in developed countries. Early research on teacher training presents a rather pessimistic view of the effectiveness of staff development for increasing student 
performance. In a meta-analysis of 93 studies of the effect of teacher development on student performance, Kennedy (1998) report that only 12 studies show positive effects of staff development. Consistent with this finding, Corcoran (1995) and Little (1993) claim that typically staff development is a low intensity affair that lacks continuity and accountability. There are some notable exceptions to these findings however. Bressoux (1996), using a quasiexperimental research design, and Dildy (1982), examining the results of a randomized trial, find that teacher training increases student performance. Wiley and Yoon (1995) and Cohen and Hill (2000) are others who find teacher development programs to have at least small impacts on student performance.

One recent paper that finds particularly strong effects of teacher training is Angrist and Lavy (2001). The authors use difference-in-difference and matching strategies to estimate the causal effect of teacher training on student math and reading performance in Jerusalem elementary schools. They find that teacher training increases student achievement by roughly 0.25 standard deviations. While this paper presents strong evidence regarding the potential effectiveness of teacher training programs, several features of the intervention limit the generalizability of the results. First, because the schools were not randomly assigned to treatment, it is possible that the schools selected for the project were on an upward (or downward) trajectory, which may bias the difference-in-difference estimates. Second, in addition to funding teacher training, the Jerusalem intervention consisted of several other components that might have increased student achievement, including the establishment of a learning center to assist failing students after school and a project to support immigrant students and their families. Finally, the training component of the program was highly structured and directed specifically toward teaching a common curriculum. 


\section{B. Background on School Reform in Chicago}

The CPS is the nation's third-largest school district, serving over 430,000 largely lowincome students. In the late eighties, then Secretary of Education William Bennett described Chicago public schools as the worst in the nation. In 1996, the CPS introduced a highly publicized reform effort that emphasized holding students, teachers and administrators accountable for academic achievement.

Under the Chicago policy, schools in which fewer than 15 percent of students met national norms on standardized reading exams were placed on academic probation. ${ }^{3}$ While several schools received waivers, 71 elementary schools serving over 45,000 students were placed on academic probation in the first year of the program. ${ }^{4}$ To improve student achievement in these schools, the CPS provided probation schools additional resources to buy staff development services from an external organization of their choice. In 1998-99, probation schools were working with 17 different external partners, including universities, non-profit organizations and independent consultants. During the first year a school was on probation, the CPS paid 100 percent of the costs of the external partner (up to $\$ 90,000$ ). In the second year, the

\footnotetext{
${ }^{3}$ The Chicago reform also included a student accountability policy in which students in third, sixth and eighth grade were required to meet minimum achievement levels in reading and math in order to move to the next grade. For more details on the student accountability policy and its impact on student outcomes, see Jacob (2002) and Jacob and Lefgren (2001).

${ }^{4}$ Probation schools that do not exhibit sufficient improvement may be reconstituted, which involves the dismissal or reassignment of teachers and school administrators. It appears that this was "cheap talk" as no elementary schools were ever reconstituted. Additionally, teacher surveys suggest that the teachers did not perceive reconstitution as a threat. In the early years of the program, in order to move off of probation, at least 20 percent of students in the school had to meet national norms in reading. In 2000, the standard was raised so that schools with fewer than 20 percent of students at national norms in reading were subject to probation and all schools needed to meet a 25 percent standard to move off of probation. In 1997-98, eight elementary schools were removed from probation because of achievement gains, but 13 additional schools were placed on probation. By 1998-99, only 54 elementary schools were on probation.
} 
reimbursement dropped to 50 percent. After two years, the Board paid one-third of the cost of external partners.

In addition to these direct resources, the CPS provided probation schools with technical assistance and monitored the progress of the school. The Office of Accountability (OA) assigned each probation school a probation manager, generally a high-level school administrator with experience as a principal, whose job was to help school staff to develop and implement a school improvement plan. Elementary schools on probation were also assigned a business manager intern to manage the operational and financial aspects of the school, freeing the principal to address educational issues and to assist the external partners in staff development.

Table 1 presents information regarding the effect of probation on teacher development (see Smylie et al. 2001 for a more detailed discussion of professional development in the CPS). ${ }^{5}$ The first two columns show that in 1994, teachers in schools that would be placed on probation in 1997 participated in school sponsored professional development at about the same rate as other teachers. In 1997 and 1999, teachers in probation schools were participating at substantially higher levels than their colleagues. In 1997, probation teachers attended an average of 3.4 professional development activities each month compared to only 2.6 activities for other teachers. ${ }^{6}$ The increase is reflected in activities sponsored by the school, teacher networks, outside partners, and the CPS. The differences in 1999 are somewhat less dramatic, which may be explained by the fact that some schools on probation in 1997 were taken off probation while

\footnotetext{
${ }^{5}$ The data used for table come from surveys conducted by the Consortium on Chicago School Research. These surveys were administered in 1994, 1997, and 1999 to all CPS teachers and asked a number of questions regarding the teachers' work environment - including the extent and nature of professional development activities. We thank the Consortium for making these data available.

${ }^{6}$ The data report participation during the past school year using ranges of values (e.g. 3-5 times in the last year). To calculate average participation we assume that teacher participation was in the midpoint of the range. We further assume teachers in the highest category attended 12 activities during the school year. We divide the number of
} 
other schools were placed on probation. This evidence suggests that probation increased the frequency of professional development activities by about 25 percent in the first year. Teachers in probation schools also believed that the quality of teacher training activities improved under probation (see Smylie et al. 2001). Finally, it is possible that teachers in probation schools received additional informal advice from probation partners.

It is also useful to put the magnitude of probation expenditures into perspective. Unfortunately, school-level records of professional development expenditures are not available. In addition, a significant fraction of the resources spent on teacher development efforts would not appear in a school's budget, including the time of principals and district administrators used to coordinate development programs and monitor teachers. Despite these challenges, it is useful to perform some back of the envelope calculations to put the magnitude of the probation policy into perspective.

Smylie et al. (2001) report that the CPS budgeted $\$ 75$ million for professional development in the 1997-1998 school year. This represented about 2.5 percent of the district's total expenditures. If teacher development expenditures were divided equally among grades (first to twelfth), then approximately $\$ 50$ million would have been spent on elementary schools and average expenditures per elementary school would have been about $\$ 108,000$. If we use this as a rough baseline for professional development expenditures, the additional financial resources that were available under the probation policy seem substantial.

reported activities by 6 (the number of months school had been in session at the time of the survey) to obtain monthly participation. 


\section{Data}

This study utilizes administrative data from the Chicago Public School system. Student records provide detailed demographic and educational background data on individual students for each academic year, including prior achievement scores, previous school and residential mobility, birth date, race, gender, family composition, free lunch status, and special education and bilingual services received. School records provide average demographic data at the school level, including percent low-income, average daily attendance, and school mean test scores. The primary outcome measures we use are math and reading scores on the Iowa Test of Basic Skills (ITBS), a multiple-choice exam that CPS students take annually in grades two to eight. The ITBS is measured in terms of grade equivalents (GEs), which reflect the years and months of learning that a student has mastered. For example, a student at national norms in sixth grade will score 6.8 GEs, which means the student has mastered material up to the eighth month of sixth grade.

The baseline sample for this study consists of the cohort of third through sixth grade students who were enrolled in a Chicago elementary school in the Fall of $1996(n=131,314)$. We limit the sample to students in these grades because we measure performance gains over three years and ITBS scores are not available for students beyond eighth grade. We delete 198 students who attended a special needs school in the Fall of 1996 and 3,981 students (three percent) who are missing student or school demographic data, which leaves us with a sample of 127,135 students in 461 different schools. $^{7}$

\footnotetext{
${ }^{7} 26,907$ of these students did not take the ITBS exam in the Spring of 1996. Most of the students with missing test scores were third graders in the Fall of 1996 because not all schools tested second grade students at this time. In order to avoid dropping these students, we set the missing 1996 test scores to zero and include a binary variable to indicate that the test score was missing. As a check, we have done the analysis excluding students with missing 1996 test scores and obtained virtually identical results.
} 
Table 2 presents summary statistics on this sample. Roughly 20 percent of students attended a school on probation at some point between 1997-99 and these students spent an average of 1.9 years in a school on probation. As one would expect, probation schools served the most disadvantaged students in the CPS. Students who spent at least one year in a probation school scored roughly six to seven months beyond their peers in math and reading in 1996 . Over 95 percent of students who attended a probation school received free lunch compared with 75 percent of students who did not attend a probation school and students in probation schools were nearly twice as likely to be living in a foster home in Fall 1996. Hispanic students were substantially less likely to attend a probation school than Black students—on average 12 percent of students attending probation schools were Hispanic compared with 25 percent of the CPS whereas nearly 87 percent of students attending probation schools were Black compared with only 60 percent in the CPS. Similarly, students in probation schools experienced school level mobility, truancy, and low-income rates considerably higher than peers in non-probation schools.

\section{Empirical Strategy}

Teacher training is one of many factors that may influence student learning. The relationship between inputs such as teacher training and learning outcomes can be captured in the following education production function:

$$
Y_{i s}=\beta_{1}(\text { Training })_{s}+\mathrm{B} X_{i}+\Gamma Z_{s}+u_{s}+v_{i}+\varepsilon_{i s} \text {, }
$$

where Y is the outcome, Training indicates whether a student's teachers received in-service training, $\mathrm{X}$ is a vector of student demographic and past performance variables, $\mathrm{Z}$ is a vector of other teacher and school characteristics, $u$ represents the effect of unobserved school quality, $v$ 
is unobserved student ability, $\varepsilon$ is an error term, and the $i$ and $s$ subscripts identify the individual and school respectively.

The difficulty in estimating the causal impact of Training is that teachers and schools may select, or be selected, into training on the basis of characteristics that are unobservable to the researcher. In the case of teacher training, it is difficult to even sign the direction of the potential bias. On one hand, as Lavy (1995) and others have noted, there is often a negative correlation between school inputs and pupil achievement because measures of socioeconomic disadvantage are used to decide which schools get the most inputs. In this case, it is likely that $\operatorname{Cov}\left(\right.$ Training, $\left.u_{s}\right)<0$, which will bias the estimate of $\beta_{1}$ downward. On the other hand, to the extent that teacher training is often a voluntary activity determined by the teachers and administrators in a particular school, it is possible that the most motivated teachers and schools seek training so that $\operatorname{Cov}\left(\right.$ Training, $\left.u_{s}\right)>0$, which will tend to bias $\beta_{1}$ upward.

The recent school reform efforts in Chicago, however, provide a unique opportunity to identify the causal impact of teacher training on student achievement. The strict test score cutoff for probation generated a highly non-linear relationship between school reading performance in 1996 and the average number of years a student spent in a school on probation between 1997 and 1999. Figure 1 illustrates the relationship between the percent of students meeting national norms in a student's 1996 school and the number of years between 1996 and 1999 that the student attended a school on probation. We can see that students enrolled in schools where 13 percent of students met national norms in 1996 attended schools on probation for an average of two years over this period. In contrast, students in schools where 15 percent of students met national norms in 1996 attended schools on probation for only 0.30 years on average over the same period. 
This discontinuity provides a way to estimate the effect of teacher training on student achievement. Assuming that unobservable characteristics do not vary discontinuously around the cutoff, the probation decision rule essentially replicates random assignment of training to schools around the cutoff. One can thus identify the treatment effect by simply comparing students in schools on either side of the cutoff. For example, if students in schools that just missed the cutoff (and were thus likely to be placed on probation and have access to the additional teacher training resources) learned much more than students in schools that just made the cutoff (and thus avoided probation), then one might conclude that the staff development and technical assistance associated with probation has a positive impact.

This strategy is often referred to as a regression discontinuity design. ${ }^{8}$ If there is a perfect relationship ${ }^{9}$ between 1996 school reading achievement and the number of years a student spends in a school on probation, then a properly specified OLS model that included a dummy variable indicating whether the student was in a school below the cutoff in 1996 would provide unbiased estimates of the training effect. However, there are several reasons that the relationship between years in a probation school and 1996 school reading achievement is not perfect. First, several schools that scored below the probation cutoff were waived from the policy (e.g., 15 of the 77 elementary schools that scored below the cutoff in 1996 received waivers). Second, 25 schools that were placed on probation in 1996-97 raised achievement enough to be removed from

\footnotetext{
${ }^{8}$ This type of regression discontinuity analysis was pioneered in educational evaluation research. In one of the first papers to introduce this design. Thistlethwaite and Campbell (1960) utilized the fact that National Merit Awards are given on the basis of whether a test score exceeds a threshold to estimate the effect of the award on a student's other scholarship receipt and college aspirations. This strategy was used widely in evaluations of compensatory education programs mandated under Title I (Trochim, 1984) as well as other contexts. Other studies to use this design include Berk and Rauma (1983), Angrist and Lavy (1999), Black (1999), Hahn et al. (1999), Jacob and Lefgren (2001) and Guryon (2001).

${ }^{9}$ By perfect relationship, we mean that the treatment is completely determined by observed performance. In this case, treatment is necessarily orthogonal to any unobserved characteristics. Thus, after controlling appropriately for
} 
probation in the next two years. Conversely, 16 schools that missed the probation cutoff in the first year were placed on probation in the following two years. Finally, there was substantial student mobility. Many students moved between probation and non-probation schools during this period.

To account for the "fuzzy" discontinuity, we utilize an instrumental variables strategy. In the first stage, we predict the number of years a student will spend in a school on probation as a function of observable student demographics and prior achievement as well as the mean reading achievement in the student's school in 1996. Specifically, the first stage equation takes the following form:

(2) Training $_{i s}=\gamma_{1}\left(\right.$ Norms $\left._{s}^{0-14}\right)+\gamma_{2}\left(\right.$ Norms $\left._{s}^{14-15}\right)+\gamma_{3}\left(\right.$ Norms $\left._{s}^{15+}\right)+\Gamma_{1} Z_{s}+\mathrm{B}_{1} X_{i}+\gamma_{4} u_{s}+\gamma_{5} v_{i}+\eta_{i, s}$ where $\mathrm{Z}$ and $\mathrm{X}$ are defined as previously indicated. The variables labeled Norms capture the nonlinear relationship observed in Figure 1. The superscripts over the Norms variables indicate the use of a spline. For example, a student in a school with 16 percent of the students at or above national norms would have a value of 14 for $N o r m s^{0-14}$, a value of 1 for $N o r m s^{14-15}$, and a value of 1 for Norms $^{15+}$. We then estimate the 1999 achievement in a two-stage least squares framework using the predicted value of the years in a probation school.

Because we know the nature of the non-linearity between school reading performance and years in a probation school ex-ante, the functional form of the selection equation provides convincing exclusion restrictions necessary for IV estimation. However, our approach does rely on several assumptions. Most importantly, we must assume that unobserved characteristics 
and/or effort vary continuously with the measured performance around the cutoff. ${ }^{10}$ This may not be true in cases where participants have precise control over their performance, particularly near the margin of interest, or in cases in which failing to achieve a cutoff is associated with additional consequences not directly related to the treatment in question.

One such concern in our case is that teachers or school administrators may attempt to influence student scores on the margin. For example, a school that knows it is in danger of probation may attempt to influence testing to get on probation (and thus get the associated resources) or get off probation (to avoid potential sanctions). While Jacob and Levitt (2002) identify cases in which Chicago teachers may have improperly assisted students on exams, this behavior appears limited to a relatively small number of classrooms and is thus unlikely to affect our results.

Another concern is student mobility. Since prior research indicates that student mobility rates are generally higher in lower achieving schools (see Kerbow, 1996; Hanushek, Kain, and Rivikin 2001), we expect to find higher mobility rates among probation schools in comparison to non-probation schools. While high mobility in itself is not problematic, if probation causes highachieving or motivated students to leave the CPS our estimates may be biased. ${ }^{11}$ Using the regression discontinuity design above, we are able to examine whether probation status itself caused certain students to leave the school or the CPS. As we show in the next section, it

\footnotetext{
${ }^{10}$ Actually, it is sufficient that the unobserved characteristics do not vary discontinuously in the same fashion as the treatment.

${ }^{11}$ If probation simply causes students to change schools within the CPS, our estimates will not be biased but the interpretation of the IV estimates may change. See Imbens and Angrist (1994) and Heckman and Vytlacil (2001) for a more detailed discussion of these issues.
} 
appears that probation did not induce student mobility, which reinforces the validity of the achievement estimates. $^{12}$

The other important assumption in our analysis involves the functional form of the relationship between current school achievement and future student achievement. Our instruments in equation (2) are nonlinear functions of school-level achievement. If the true relationship between school mean achievement and future student performance is non-linear for the range of values we examine, the estimated treatment effect could reflect underlying nonlinearity in the achievement relationship.

While this concern is mitigated to some extent since we examine schools within a limited range around the probation cutoff, we nonetheless examine whether it is a serious concern in this study. First, we estimate models that allow for school mean achievement in 1996 to influence future student performance in a non-linear fashion by including second and third order polynomials in equations (1) and (2). Second, we include a cohort of students who were enrolled in third to sixth grade in 1993, prior to the introduction of the Chicago school accountability reforms. This allows us to control for the nonlinear function of school achievement that we use as instruments in our baseline specification. For this specification, we obtain instruments by interacting the spline of school reading achievement with a dummy that takes a value of one if the probation policy was in effect. If the relationship between school and student achievement is stable over time, this procedure will guarantee that our findings are not driven by non-linearity in the effect of school reading performance on student performance. In the next section, we show that this does not change our results.

\footnotetext{
${ }^{12}$ Because the probation policy was not commonly known until the beginning of the 1996-1997 school year, it seems unlikely that students would have shifted schools before this point.
} 


\section{Results}

\section{A. Main Findings}

Under the assumptions described above, if teacher training has a substantial impact on academic achievement, we would expect to see a rapid change in the average achievement level around the probation cutoff. Figure 2 provides a way to visually identify the treatment effect. The heavy solid line shows the average number of years the student attended a school on probation between 1996-97 and 1998-99. The other lines show the average 1999 reading (solid line) and math (broken line) achievement respectively. If the teacher training associated with probation were beneficial, we would expect to see a drop in performance as school reading performance neared and surpassed the cutoff.

As expected, we see that 1999 student achievement increases as a function of 1996 school mean achievement. However, the lines are relatively jagged, reflecting the fact that there are a limited number of schools at each level of school performance. The dark vertical lines at 13 and 16 percent bound the marginal area, where there is a sharp decline in the treatment. Average 1999 achievement increases steadily over this range, but does not appear to change discontinuously in reading or math, particularly in comparison to other jagged areas of the graph (e.g., 18-20 percent, 11-13 percent). This suggests that the teacher training in Chicago did not have a substantial impact on student achievement.

Using the instrumental variables strategy described above, we can quantify our estimates of the treatment effect. In the baseline specifications, we limit our sample to students in lowperforming schools where between 5 and 25 percent of students met national norms in 1996. We do so because the assumption of linearity between school reading achievement and student performance is most plausible in this narrower ranges of the data. Additionally, by focusing on a 
narrow range around the cutoff, schools and students that receive treatment are likely to be comparable to their untreated counterparts. We later show that the results are robust to changes in the sample and model specification.

Table 3 presents the results of the first stage estimation. The dependent variable is the number of years a student attended a school on probation between the 1996-1997 and 1998-1999 school years (ranging from zero to three). Note that all of the coefficients have the expected signs and the instruments are highly predictive.

Table 4 presents the OLS and IV estimates. The OLS estimate in column 1 of -0.098 indicates that one additional year in a school on probation is associated with a decrease of roughly one month of learning $(0.10 \mathrm{GEs})$ in reading and math. However, we know from Table 2 that probation schools served a significantly more disadvantaged student population than other schools. When we control for a variety of observable student and school characteristics, our estimates drop to one-fifth of this size, although they remain negative and significant.

Columns three to six present the IV estimates. All of these estimates suggest that probation has no economically or statistically important effect on reading and math achievement. The coefficient with the largest absolute magnitude, -0.026 , corresponds to roughly a 0.01 standard deviation effect. Note that the standard errors on the IV estimates in column six are roughly 0.025 , meaning that we could detect a positive significant result as small as 0.05 GEs. Considering that the average elementary student during this period gained roughly 0.90 GEs per year and the standard deviation of 1999 achievement scores in our sample was roughly 1.9 GEs, 
it does not appear that the teacher training and/or technical assistance provided to probation schools had any meaningful effect. ${ }^{13}$

In addition, note that the results from columns four to six show that our IV results are not sensitive to the inclusion of control variables. This suggests that after controlling for school reading performance, students in schools just above and below the cutoff have comparable observable characteristics. This lends more credence to the assumption that the unobserved characteristics of students in schools just above and below the cutoff are comparable as well. Finally, we see that there is no significant difference between the OLS and IV results presented in columns four and six. This suggests that, conditional on the set of student and school controls included in the models, probation waivers were not distributed on the basis of unobservable characteristics.

\section{B. Other Effects of Probation}

As was mentioned previously, probation might influence student mobility and test-taking patterns. In particular, motivated families may want to remove their children from probation schools and probation schools may want to avoid testing the lowest ability children. Using the IV methodology described above, we examine the causal impact of being in a probation school in 1996-97 on the probability that a student changes schools, leaves the CPS, or fails to have an included test score. These results are found in Table 5.

\footnotetext{
${ }^{13}$ This strategy identifies the net effect of attending a school on probation compared to a school that just missed being placed on probation. In addition to the teacher training and technical assistance, probation schools may have experienced somewhat different incentives than those schools that just missed the cutoff for probation. Because schools that just missed being placed on probation in 1996 were at risk of being placed on probation in subsequent years, they too had an incentive to increase student performance. However, to the extent that schools that were placed on probation in 1996 were one step closer to actual sanctions, they may have had even greater incentives to increase achievement. Note that these three mechanisms - teacher training, technical assistance and differential incentives - all operate in the same direction, suggesting that students in schools placed on probation in 1996 should outperform students in schools who narrowly avoided probation that year.
} 
The first row suggests that being in a probation school in 1997 has no significant effect on the probability of being enrolled in the CPS in 1999. Because there are few high achieving students in probation schools it is difficult to ascertain whether probation has a differential effect on the enrollment decisions of high ability students.

In the second row, we see that probation appears to increase the probability that a student changes schools by 1999. Furthermore, the point estimates are not trivial relative to the baseline mobility of 24 percent, particularly among the top ability quartile. Despite this, the coefficients are not significantly different from zero. The standard errors are particularly large for the high ability students. Taken at face value, however, the point estimates suggest that probation may have induced high ability students to change schools.

Finally, it does not appear that being in a probation school is associated with changes in the probability that a previously tested student has test scores is included for evaluation. This holds even for students who are in the bottom of national reading distribution. This suggests that being put on probation does not cause administrators to discourage low ability students from being tested or from having the test scores counted for school evaluation. Overall, probation may affect student decision regarding school attendance within the CPS. However, there is no evidence that being in a probation school in 1997 causes students to leave the district, avoid testing, or have their scores excluded for evaluation purposes.

Because students who change schools but remain in the district are retained in our sample, there is no reason to believe our point estimates are biased by differential attrition of high and low ability students. This is true because although the treatment is at the school level, we are examining student level outcomes and are not attributing average school level changes in performance due to student migration to the probation policy. To see this, consider the situation 
in which high ability students leave probation schools and move to non-probation schools within the CPS. If high ability students leave probation schools, then the difference in outcomes between students who initially attended schools below and above the cutoff will be lower than otherwise. However, the difference in treatment will be lower as well. Since the IV estimates essentially scale the difference in outcomes by the difference in treatment, the IV treatment effect estimate will not be biased. However, because our instruments will induce more variation in the treatment of low ability students than high ability students, the estimated treatment effect will reflect disproportionately the experience of low ability students. In this way migration simply changes the Local Average Treatment Effect (LATE) interpretation of our results. Insofar as the probation policy and teacher training resources were primarily aimed at improving performance of low-ability students, the IV estimates provide quite important and useful information.

\section{Heterogeneous Effects and Robustness Checks}

Table 6 examines the heterogeneity of effects by student age, ability, and other demographic characteristics. Each row corresponds to a separate regression that includes only students in the subgroup listed. The cells contain IV estimates of the effect of the number of years in a probation school on 1999 achievement. The top panel shows that probation has no effect on student performance in any grade from third to sixth in either reading or math. The second panel shows separate effects for students at different points in the ability distribution in Spring 1996. Because probation is determined by the percent of students who score above the $50^{\text {th }}$ percentile, the policy creates an incentive for schools to focus attention on students near this point, since they are more likely to meet this standard with sufficient support. However, we see that probation does not appear to have any larger effect on students in the second and third 
quartiles than on students at the extremes of the ability distribution. The third panel shows no difference in impact across race, gender, or SES.

Table 7 displays results from a number of alternative specifications. The first row presents the original estimates from Table 3 as a basis for comparison. In the second row, we include students from all schools—-regardless of the average school reading performance in 1996 - which should increase the efficiency of our estimates. Once again we find probation to have no significant effect on reading and math achievement. When we include third order polynomials of school performance in the third row, we find that our results do not significantly differ from the case in which we assume linearity. In rows four to six, we include a cohort of students from 1993, prior to the introduction of the school reforms. While no students or schools in this cohort received the treatment, we can use these data to make certain our findings are not driven by non-linearity in the relationship between school reading performance and student achievement. The instruments in these models are the interaction between the splines of school reading performance and cohort. We see that the estimates do not change for either reading or mathematics.

Many of the schools that scored just above the probation cutoff, or were waived from probation, were placed on remediation. These schools did not receive the same close monitoring or financial support as probation schools, but they were subject to somewhat heightened oversight. To check whether this heightened oversight may have impacted achievement, row seven examines whether being in a school on probation or remediation has any effect on academic achievement. ${ }^{14}$ We find no effect.

\footnotetext{
${ }^{14}$ For this specification, our instrument is a single dummy variable indicating whether 15 percent or more students in a school performed at or above national norms in reading in 1996, rather than the spline in 1996 reading achievement that is used in the baseline specification. We do so because the discontinuity between 1996 school mean reading
} 
Even after schools were taken off probation, they were required to maintain a relationship with their external partner for an additional year. Also, some low performing schools that were not placed on probation chose to hire an external partner even though it was not officially required. To test whether the presence of an external partner, rather than simply being on probation, influenced achievement levels in low-achieving elementary schools, row eight of Table 7 shows the estimated effect of being in a school with an external partner. This effect is not statistically different from zero. ${ }^{15}$

One might argue that the monitoring and staff development that probation schools receive should not have an observable impact on student achievement for several years. The final two rows in Table 7 explore this possibility. In row 9, we examine the effect of probation on students who remained in the same school between 1996 and 1999. Thus, in this sample, the students in probation schools received three full years of treatment. If one believes that probation has a greater impact for students who spend an extended period in the school, then these estimates should be larger than the original estimates. However, it appears that even these students received no significant benefit from being in a school on probation. It is possible that reforms instituted by the external partners and probation managers took a year or two to become effective, in which case one would not expect any impacts until the 1998-99 school year. By examining the three-year period, we will observe a small, diluted effect. To explore this possibility, row 10 shows the effect of probation on 1998-99 gains, but still finds no effect. Finally, row 11 shows the effect of probation on 1998-99 gains for the sub-sample of students

achievement and the average years in a school on probation or remediation is extremely sharp at the official probation cutoff of 15 percent, in contrast to the baseline specification that uses years on probation alone. ${ }^{15}$ Once again, our instrument is a single dummy variable that indicates whether at least 15 percent of students in a school performed at or above national norms in reading in 1996. 
who remained in the same school between 1996 and 1999. The point estimates are not statistically different than zero.

A wide variety of non-profit organizations and universities worked with probation schools in order to improve student achievement. These external partners varied considerably in their institutional affiliation (e.g., universities versus private organizations), programmatic focus (e.g., school organization versus staff training versus curriculum development) and educational philosophy (e.g., whole-language versus direct instruction). It is possible that some external partners were more effective than others, which might explain the weak aggregate effects that we find. Note, however, that the zero net effect implies that if some external partners increased student performance then others must have decreased student achievement levels. Table 8 examines the probation effects for several of the largest external partners. Because schools were largely free to select their external partner, these estimates cannot be interpreted as causal effects, although they may still provide some insight. Nonetheless, it does not appear that any of the major external partners had a significant impact on student achievement in the probation schools.

\section{Conclusions}

In an effort to improve student achievement in Chicago in the mid-nineties, the CPS placed nearly 20 percent of the lowest achieving elementary schools in the city on probation. The financial and technical support provided to probation schools was dedicated specifically to improving classroom instruction, primarily through teacher training and staff development. Indeed, teachers in probation schools reported moderate increases in the frequency with which they attended professional development activities as well as more substantial increases in the quality of the professional development they received. 
The preceding analysis, however, indicates that the training provided to teachers in probation schools had no discernable effect on student achievement. These results are robust to a variety of alternative specifications and do not differ across student ability, gender, race, or family income. While consistent with much of the earlier research on teacher training in the United States, these findings are in stark contrast to the recent work of Angrist and Lavy (2001), who found that teacher training in Jerusalem schools yielded large dividends in terms of student performance.

While it may not be surprising that different programs in different settings have different effects, it is useful to examine some of the possible explanations for the discrepancies in order to better understand how the results from each study might be generalized. Several differences stand out between the Chicago and Jerusalem programs. First, the Chicago program was implemented in a group of extremely high-poverty, low-achieving schools. In contrast, the program in Jerusalem took place in mostly middle to lower-middle class neighborhoods, which included a combination of some upper middle class schools attended by children of Hebrew University faculty as well as some poorer schools attended by immigrants (Angrist 2001). Second, the training provided in the Jerusalem schools was highly structured and closely aligned with the school curriculum whereas the training in Chicago was relatively unstructured and less well aligned. Finally, the training in Jerusalem was complemented by direct services to students in the form of after school learning centers and other programs for immigrant families.

In this light, one might interpret the findings of these two studies as showing that teacher training can have a significant, positive impact on student achievement under generally favorable conditions, but that such benefits depend on the context and quality of the program. Unfortunately, national data suggest that the frequency and nature of professional development 
activities in Chicago is comparable to other school districts in this country (Parsad et. al. 2001). Thus, our findings suggest that moderate increases in the intensity of the professional development efforts along the lines of the Chicago program will likely fail to improve the achievement of students in failing schools. 


\section{References}

Angrist, J. D. and V. Lavy (1999). "Using Maimonides Rule to Estimate the Effect of Class Size on Scholastic Achievement." Quarterly Journal of Economics 114(2): 535-75.

Angrist, J. D. and V. Lavy (2001). "Does Teacher Training Affect Pupil Learning? Evidence from Matched Comparisons in Jerusalem Public Schools.” Journal of Labor Economics 19(2): 343-369.

Angrist, J.D. (2001). Personal communication.

Berk, R. A. and D. Rauma (1983). "Capitalizing on Nonrandom Assignment to Treatments: A Regression-Discontinuity Evaluation of a Crime-Control Program.” Journal of the American Statistical Association 78(381): 21-28.

Black, S. (1996). Do Better Schools Matter? Parents Think So! Cambridge, MA.

Bressoux, P. (1996) “The Effect of Teachers' Training of Pupils' Achievement: The Case of Elementary Schools in France." School Effectiveness and School Improvement 7 (3): 252-279.

Cohen, D. F. and H. C. Hill (2000). "Instructional Policy and Classroom Performance: The Mathematics Reform in California." Teachers College Record 102(2): 294-343.

Corcoran, T. B. (1995). “Helping Teachers Teach Well: Transforming Professional Development." CPRE Policy Briefs.

Dildy, P. (1982) "Improving Student Achievement by Appropriate Teacher In-Service Training: Utilizing Program for Effective Teaching (PET)." Education 102 (2): 132-138.

Guryan, J. (2000) "Does Money Matter? Regression Discontinuity Estimates from Education Finance Reform in Massachusetts." University of Chicago Working Paper. 
Hanushek, E. A. (1996). “School Resources and Student Performance.” In Does Money Matter? The Effect of School Resources on Student Achievement and Adult Success, ed. Burtless, G. Washington D.C.: Brookings Institution Press.

Hanushek, E. A., J. F. Kain, and S. G. Rivkin (2001) "Disruption versus Tiebout Improvement: The Costs and Benefits of Switching Schools.” Working Paper.

Hedges, L. V. and R. Greenwald (1996). "Have Times Changed? The Relation between School Resources and Student Performance." In Does Money Matter? The Effect of School Resources on Student Achievement and Adult Success, ed. Burtless, G. Washington D.C.: Brookings Institution Press.

Imbens, G. W. and J. D. Angrist (1994). "Identification and Estimation of Local Average Treatment Effects.” Econometrica 62(2): 467-475.

Jacob, B. A. (2002). “Accountability, Incentives and Behavior: Evidence from High-Stakes Testing in Chicago." Working Paper.

Jacob, B. A. and S. D. Levitt (2002). "Rotten Apples: An Investigation of the Prevalence and Predictors of Teacher Cheating.” Working Paper.

Jacob, B. A. and L. Lefgren (2001). "Remedial Education and Student Achievement: QuasiExperimental Evidence from Reform Efforts in Chicago.” Working Paper.

Hahn, J., P. Todd, et al. (1999). Evaluating the Effect of an Antidiscrimination Law Using a Regression-Discontinuity Design. NBER Working Paper \#7131. Cambridge, MA.

Heckman, J. And E. Vytlacil (2001) “Local Instrumental Variables.” In Nonlinear Statistical Inference: Essays in Honor of Takeshi Amemiya, ed. C. Hsiao, K. Morimune, and J. Powell, Cambridge University Press, Cambridge. 
Kennedy, M. M. (1998). "Form and Substance in Inservice Teacher Education." Research Report from the National Institute for Science Education, University of Wisconsin.

Kerbow, D. (1996). "Patterns of Urban Student Mobility and Local School Reform." Journal of Education for Students Placed at Risk 1 2:147-169.

Ladd, H. F. (1999). "The Dallas School Accountability and Incentive Program: An Evaluation of its Impacts on Student Outcomes." Economics of Education Review 18: 1-16.

Lavy, V. (1995) "Endogenous School Resources and Cognitive Achievement in Primary Schools in Israel.” Discussion Paper no. 95.03. Jerusalem: Falk Institute for Economic Research in Israel.

Little, J. W. (1993). “Teacher's Professional Development in a Climate of Educational Reform." Educational Evaluation and Policy Analysis 15 2: 129-151.

Parsad, B., L. Lewis, E. Farris, and B. Greene (2001) "Teacher Preparation and Professional Development 2000." National Center for Educational Statistics publication 2001-088.

Richards, C. E. and T. M. Sheu (1992). "The South Carolina School Incentive Reward Program: A Policy Analysis." Economics of Education Review 11 1: 71-86.

Roderick, M., B. Jacob, and A. Bryk (2000). “Evaluating Chicago's Efforts to End Social Promotion." In Governance and Performance: New Perspectives, eds. Lynn, L. and C. Heinrich. Washington D.C.: Georgetown University Press.

Smylie, M. A., E. Allensworth, R. C. Greenberg, R. Harris, and S. Luppescu (2001). "Teacher Professional Development in Chicago: Supporting Effective Practice." Consortium on Chicago School Research report.

Thistlewaite, D. and D. Campbell (1960). "Regression-Discontinuity Analysis: An Alternative to the Ex-Post Facto Experiment.” Journal of Educational Psychology 51: 309-317. 
Trochim, W. (1984). Research Design for Program Evaluation: The Regression-Discontinuity Approach. Beverley Hills, CA, Sage Publications.

Wiley, D. E. and B. Yoon (1995). "Teacher Reports on Opportunity to Learn: Analyses of the 1993 California Learning Assessment System (CLAS).” Educational Evaluation and Policy Analysis 17 3: 355-370. 


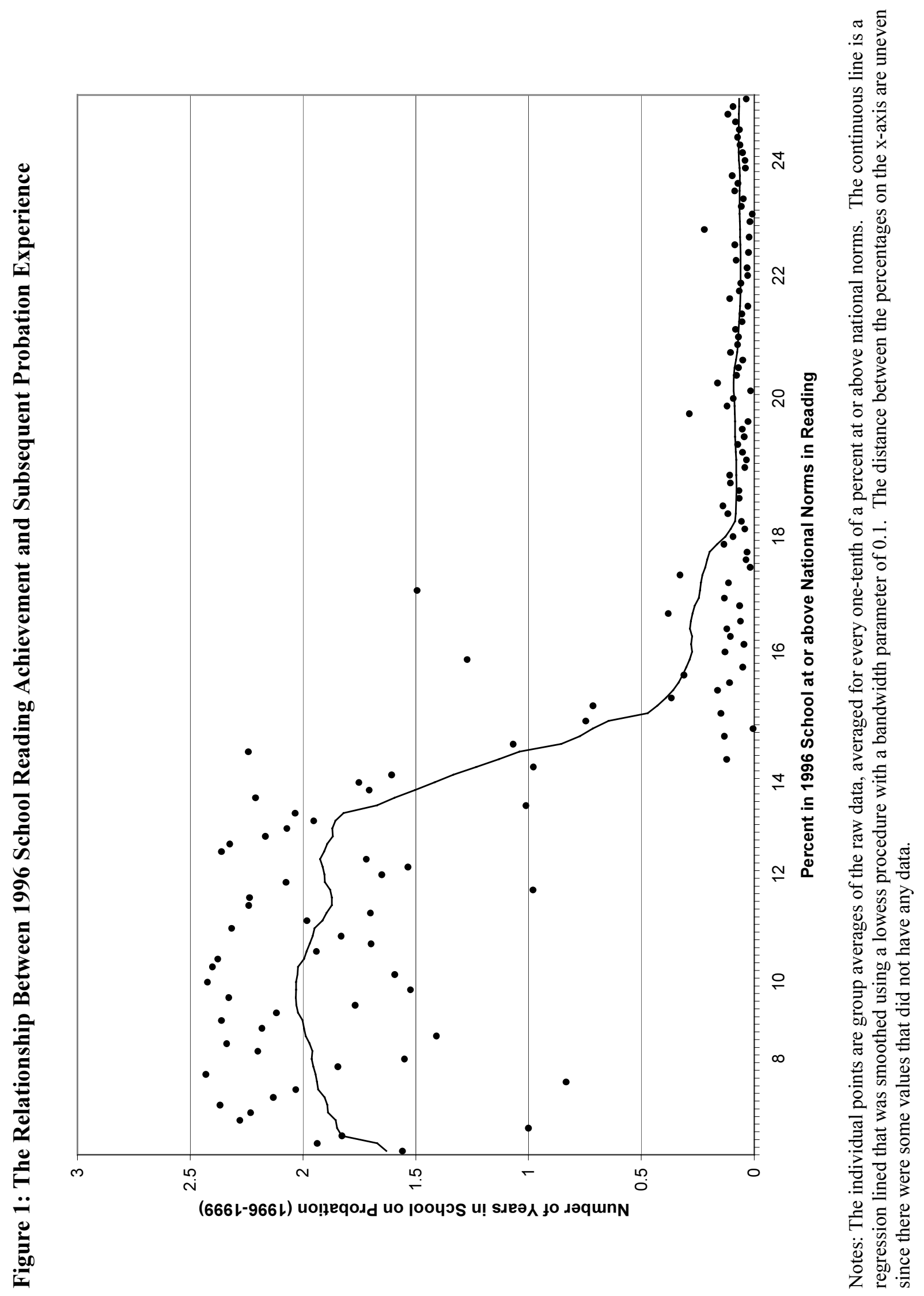




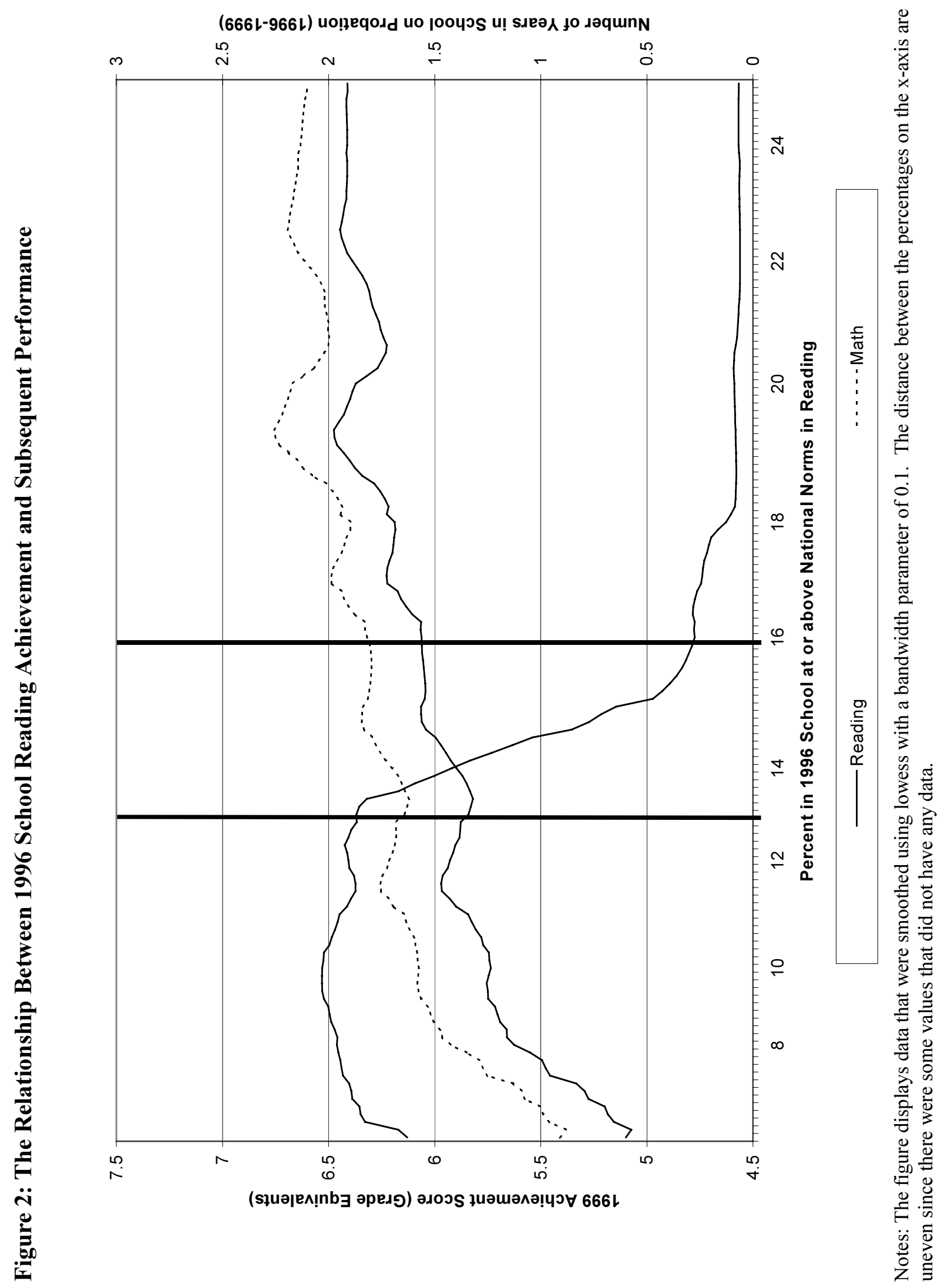


Table 1

Monthly Participation in Professional Development Activities by 1997 Probation Status

\begin{tabular}{lcccccc}
\hline \multirow{2}{*}{\multicolumn{1}{c}{ Variable }} & \multicolumn{2}{c}{1994} & \multicolumn{2}{c}{1997} & \multicolumn{2}{c}{1999} \\
\cline { 2 - 7 } & Probation & Other & Probation & Other & Probation & Other \\
& Schools & Schools & Schools & Schools & Schools & Schools \\
\hline All Activities & 3.119 & 2.976 & 3.420 & 2.644 & 3.445 & 2.877 \\
& $(2.167)$ & $(2.206)$ & $(2.432)$ & $(2.110)$ & $(2.440)$ & $(2.205)$ \\
\hline Activities with & 1.174 & 1.129 & 1.069 & .821 & 1.114 & .881 \\
Own School & $(.645)$ & $(.679)$ & $(.708)$ & $(.650)$ & $(.761)$ & $(.682)$ \\
\hline Activities with & .443 & .470 & .723 & .596 & .799 & .644 \\
Teacher Network & $(.520)$ & $(.594)$ & $(.676)$ & $(.655)$ & $(.706)$ & $(.669)$ \\
\hline Activities with & .496 & .469 & .645 & .494 & .642 & .498 \\
Outside Partner & $(.547)$ & $(.558)$ & $(.644)$ & $(.590)$ & $(.647)$ & $(.601)$ \\
\hline Activities with & .347 & .302 & .393 & .288 & .374 & .341 \\
District & $(.454)$ & $(.454)$ & $(.515)$ & $(.421)$ & $(.508)$ & $(.494)$ \\
\hline Activities with & .255 & .201 & .195 & .152 & .226 & .174 \\
Union & $(.407)$ & $(.373)$ & $(.408)$ & $(.352)$ & $(.442)$ & $(.393)$ \\
\hline Activities with & .503 & .406 & .412 & .348 & .348 & .345 \\
College or & $(.650)$ & $(.601)$ & $(.640)$ & $(.581)$ & $(.594)$ & $(.598)$ \\
University & 215 & 936 & 365 & 2,068 & 145 & 1,375 \\
\hline Observations & & & & & & \\
\hline
\end{tabular}

Notes for Table 1: Probation status refers to the probation status of the school in 1997. Standard deviations are in parentheses. Data come from teacher surveys generously provided by the Consortium on Chicago School Research. 
Table 2

Summary Statistics

\begin{tabular}{|c|c|c|c|}
\hline $\begin{array}{c}\text { Means } \\
\text { (standard deviations) }\end{array}$ & Total & $\begin{array}{c}\text { Never in school on } \\
\text { probation between } \\
1997 \text { and } 1999\end{array}$ & $\begin{array}{c}\text { In school on } \\
\text { probation for at } \\
\text { least one year } \\
\text { between } 1997 \text { and } \\
1999\end{array}$ \\
\hline \multicolumn{4}{|l|}{ Treatment } \\
\hline In school on probation in 1997 & 0.140 & 0.000 & 0.772 \\
\hline Years in school on probation from 1997 to 1999 & 0.334 & 0.000 & 1.889 \\
\hline \multicolumn{4}{|l|}{ Student Outcomes } \\
\hline 1999 Reading Score & $\begin{array}{c}6.372 \\
(1.995)\end{array}$ & $\begin{array}{c}6.530 \\
(1.995)\end{array}$ & $\begin{array}{c}5.671 \\
(1.838)\end{array}$ \\
\hline 1999 Math Score & $\begin{array}{c}6.630 \\
(1.821)\end{array}$ & $\begin{array}{c}6.777 \\
(1.814)\end{array}$ & $\begin{array}{c}5.978 \\
(1.707)\end{array}$ \\
\hline Not tested in 1999 & 0.163 & 0.171 & 0.126 \\
\hline Tested, but excluded from reporting in 1999 & 0.163 & 0.163 & 0.164 \\
\hline Enrolled in the CPS & 0.860 & 0.851 & 0.904 \\
\hline Changed schools (left 1996 school) & 0.240 & 0.211 & 0.371 \\
\hline \multicolumn{4}{|l|}{ Student Demographics } \\
\hline 1996 Reading Score & $\begin{array}{c}3.571 \\
(1.623)\end{array}$ & $\begin{array}{c}3.704 \\
(1.649)\end{array}$ & $\begin{array}{c}2.998 \\
(1.363)\end{array}$ \\
\hline 1996 Math Score & $\begin{array}{c}3.877 \\
(1.359)\end{array}$ & $\begin{array}{c}3.988 \\
(1.376)\end{array}$ & $\begin{array}{c}3.397 \\
(1.169)\end{array}$ \\
\hline Tested, but excluded from reporting in 1996 & 0.069 & 0.068 & 0.071 \\
\hline Black & 0.534 & 0.476 & 0.802 \\
\hline Hispanic & 0.322 & 0.351 & 0.190 \\
\hline Male & 0.506 & 0.505 & 0.511 \\
\hline Black Male & 0.267 & 0.237 & 0.408 \\
\hline Hispanic Male & 0.165 & 0.179 & 0.098 \\
\hline Age in June 1996 & $\begin{array}{l}10.146 \\
(1.243)\end{array}$ & $\begin{array}{l}10.152 \\
(1.242)\end{array}$ & $\begin{array}{l}10.117 \\
(1.247)\end{array}$ \\
\hline Free Lunch & 0.798 & 0.764 & 0.957 \\
\hline Reduced Price Lunch & 0.082 & 0.094 & 0.027 \\
\hline Currently in Bilingual Program & 0.196 & 0.211 & 0.124 \\
\hline Formerly in Bilingual Program & 0.154 & 0.175 & 0.057 \\
\hline Special Education & 0.116 & 0.115 & 0.117 \\
\hline Living with Relatives & 0.132 & 0.143 & 0.080 \\
\hline Living in Foster Care & 0.044 & 0.039 & 0.071 \\
\hline Concentration of Poverty (block group) & $\begin{array}{c}0.233 \\
(0.713)\end{array}$ & $\begin{array}{c}0.107 \\
(0.646)\end{array}$ & $\begin{array}{c}0.818 \\
(0.722)\end{array}$ \\
\hline Social Status (block group) & $\begin{array}{l}-0.280 \\
(0.687)\end{array}$ & $\begin{array}{l}-0.197 \\
(0.687)\end{array}$ & $\begin{array}{l}-0.667 \\
(0.538)\end{array}$ \\
\hline Third grade & 0.268 & 0.264 & 0.288 \\
\hline Fourth grade & 0.250 & 0.249 & 0.254 \\
\hline Fifth grade & 0.241 & 0.242 & 0.237 \\
\hline Sixth grade & 0.241 & 0.245 & 0.222 \\
\hline \multicolumn{4}{|l|}{ School Characteristics } \\
\hline Enrollment & $\begin{array}{c}781 \\
(316)\end{array}$ & $\begin{array}{c}793 \\
(329)\end{array}$ & $\begin{array}{c}723 \\
(244)\end{array}$ \\
\hline Attendance Rate & 92.6 & 93.1 & 90.7 \\
\hline Mobility Rate & 29.3 & 28.0 & 35.6 \\
\hline
\end{tabular}




\begin{tabular}{l|c|c|c|}
\hline Truancy Rate & 2.5 & 1.9 & 5.1 \\
\hline Percent Black & 53.3 & 47.8 & 79.1 \\
\hline Percent Hispanic & 32.1 & 34.7 & 19.7 \\
\hline Percent Limited English Proficient & 17.4 & 18.8 & 10.9 \\
\hline Percent Low Income & 85.4 & 83.3 & 95.1 \\
\hline Number of Observations & 127,135 & 104,687 & 22,448 \\
\hline
\end{tabular}

Notes to Table 2: The sample includes students who were in the third through sixth grades in Fall 1996. We exclude children who were missing demographic information. We also drop observations with missing school demographic variables as well as all students in special needs schools. 


\section{Table 3}

The Effect of the 1996 School Reading Performance on the Average Years a Student Spends in a School on Probation between 1997 and 1999

\begin{tabular}{l|c|}
\hline \multicolumn{1}{c|}{ Independent Variables } & $\begin{array}{c}\text { Dependent Variables } \\
\text { (1) at or Above National Norms in Reading }\end{array}$ \\
\hline $\begin{array}{l}\text { Number of years a student spends in a school on } \\
\text { probation from 1997 to 1999 }\end{array}$ \\
\hline$\%$ at or Above National Norms in Reading & 0.018 \\
$(14 \%-15 \%)$ & $(0.026)$ \\
\hline$\%$ at or Above National Norms in Reading & -1.724 \\
$(15 \%-25 \%)$ & $(0.124)$ \\
\hline Number of Schools & -0.021 \\
\hline Number of Observations & $(0.010)$ \\
\hline R-Squared & 246 \\
\hline F-Statistic of Instruments & 47,274 \\
\hline
\end{tabular}

Notes to Table 3: Sample includes students who were in schools in the Fall of 1996 that had between 5\% and 25\% of students at or above national norms in reading. The F-statistic of the instruments takes into account that the instruments are jointly collinear with the second stage control variable "\% at or above national norms in reading." All test statistics are computed taking into account that observations within a school may not be independent. The regression includes the following variables that are not shown here: 1996 math and reading scores, student demographics including whether the student was included for test reporting purposes in 1996, age as of Fall 1996, race and gender indicators (Black, Hispanic, male, Black*male, Hispanic*male), free and reduced price lunch status, current and former bilingual status, special education, an indicator of whether the student was living with relatives or living in foster care, concentration of poverty and social status in the student's census block group, and school demographics including the attendance rate, percent Black, percent Hispanic, percent LEP, percent low income, mobility rate, truancy rate, and percent at or above national norms in math. 
Table 4

IV and OLS Estimates of the Effect of Teacher Training on Student Achievement

\begin{tabular}{lcccccc}
\hline \multicolumn{1}{c}{$\begin{array}{c}\text { Dependent } \\
\text { Variables }\end{array}$} & OLS & OLS & OLS & IV & IV & IV \\
\hline 1999 Reading Scores & -0.098 & -0.085 & -0.020 & -0.026 & -0.020 & -0.007 \\
{$[\mathrm{n}=47,274]$} & $(0.019)$ & $(0.018)$ & $(0.010)$ & $(0.029)$ & $(0.027)$ & $(0.022)$ \\
1999 Math Score & -0.093 & -0.077 & -0.021 & -0.015 & -0.006 & 0.005 \\
{$[\mathrm{n}=47,118]$} & $(0.018)$ & $(0.017)$ & $(0.010)$ & $(0.032)$ & $(0.028)$ & $(0.026)$ \\
\hline $\begin{array}{l}\text { Student Level } \\
\text { Covariates }\end{array}$ & No & No & Yes & No & No & Yes \\
$\begin{array}{l}\text { School Level } \\
\text { Covariates }\end{array}$ & No & Yes & Yes & No & Yes & Yes \\
\hline
\end{tabular}

Notes to Table 4: Sample includes students who were in schools in the Fall of 1996 that had between $5 \%$ and $25 \%$ of students at or above national norms in reading. 
Table 5

IV Estimates of the Effect of Being in a Probation School in 1997

\begin{tabular}{|c|c|c|c|c|c|}
\hline & \multicolumn{5}{|c|}{ Sample } \\
\hline $\begin{array}{l}\text { Dependent } \\
\text { Variable }\end{array}$ & Full Sample & $\begin{array}{l}1^{\text {st }} \text { Quartile } \\
\text { of National } \\
\text { Reading } \\
\text { Distribution }\end{array}$ & $\begin{array}{l}2^{\text {nd }} \text { Quartile } \\
\text { of National } \\
\text { Reading } \\
\text { Distribution }\end{array}$ & $\begin{array}{l}3^{\text {rd }} \text { Quartile } \\
\text { of National } \\
\text { Reading } \\
\text { Distribution }\end{array}$ & $\begin{array}{l}4^{\text {th }} \text { Quartile } \\
\text { of National } \\
\text { Reading } \\
\text { Distribution }\end{array}$ \\
\hline $\begin{array}{l}\text { Enrolled in CPS in } \\
1999[\mathrm{n}=53,767]\end{array}$ & $\begin{array}{l}-0.002 \\
(0.008)\end{array}$ & $\begin{array}{l}-0.005 \\
(0.009)\end{array}$ & $\begin{array}{c}0.016 \\
(0.011)\end{array}$ & $\begin{array}{l}-0.022 \\
(0.017)\end{array}$ & $\begin{array}{l}-0.026 \\
(0.040)\end{array}$ \\
\hline $\begin{array}{l}\text { Changed schools by } \\
1999[n=43,638]\end{array}$ & $\begin{array}{c}0.034 \\
(0.022)\end{array}$ & $\begin{array}{c}0.039 \\
(0.026)\end{array}$ & $\begin{array}{c}0.031 \\
(0.023)\end{array}$ & $\begin{array}{c}0.014 \\
(0.037)\end{array}$ & $\begin{array}{c}0.069 \\
(0.058)\end{array}$ \\
\hline $\begin{array}{l}\text { Not tested in } 1999 \\
{[n=53,767]}\end{array}$ & $\begin{array}{c}0.004 \\
(0.008)\end{array}$ & $\begin{array}{c}0.013 \\
(0.010)\end{array}$ & $\begin{array}{l}-0.018 \\
(0.012)\end{array}$ & $\begin{array}{c}0.007 \\
(0.018)\end{array}$ & $\begin{array}{c}0.045 \\
(0.041)\end{array}$ \\
\hline $\begin{array}{l}\text { Excluded in } 1999 \\
{[n=47,075]}\end{array}$ & $\begin{array}{l}-0.015 \\
(0.008)\end{array}$ & $\begin{array}{l}-0.023 \\
(0.012)\end{array}$ & $\begin{array}{l}-0.002 \\
(0.006)\end{array}$ & $\begin{array}{c}0.002 \\
(0.005)\end{array}$ & $\begin{array}{l}-0.004 \\
(0.005)\end{array}$ \\
\hline $\begin{array}{l}\text { Not tested or } \\
\text { excluded in } 1999 \\
{[n=53,767]}\end{array}$ & $\begin{array}{l}-0.009 \\
(0.010)\end{array}$ & $\begin{array}{l}-0.008 \\
(0.014)\end{array}$ & $\begin{array}{l}-0.018 \\
(0.011)\end{array}$ & $\begin{array}{c}0.010 \\
(0.019)\end{array}$ & $\begin{array}{c}0.038 \\
(0.041)\end{array}$ \\
\hline
\end{tabular}

Notes to Table 5: Baseline sample includes students who were in schools in the Fall of 1996 that had between 5\% and $25 \%$ of students at or above national norms in reading. Also included (but not shown) in the regression specification are the controls described in Table 2. All estimates are computed using two stage least squares. The instruments and controls are as previously indicated. 
Table 6

The Effect of Probation on Student Achievement

\begin{tabular}{|c|c|c|}
\hline \multirow[b]{2}{*}{ Subgroup } & \multicolumn{2}{|c|}{ Probation Treatment Effect } \\
\hline & 1999 Reading Score & 1999 Math Score \\
\hline \multicolumn{3}{|l|}{ Grade Level } \\
\hline Third Grade & $\begin{array}{c}0.053 \\
(0.036) \\
\end{array}$ & $\begin{array}{c}0.038 \\
(0.040)\end{array}$ \\
\hline Fourth Grade & $\begin{array}{l}-0.017 \\
(0.033)\end{array}$ & $\begin{array}{l}-0.001 \\
(0.032)\end{array}$ \\
\hline Fifth Grade & $\begin{array}{l}-0.039 \\
(0.036)\end{array}$ & $\begin{array}{c}0.001 \\
(0.037)\end{array}$ \\
\hline Sixth Grade & $\begin{array}{l}-0.014 \\
(0.037)\end{array}$ & $\begin{array}{c}0.000 \\
(0.041)\end{array}$ \\
\hline \multicolumn{3}{|l|}{ Prior Achievement } \\
\hline $1^{\text {st }}$ Quartile National Reading Distribution & $\begin{array}{l}-0.017 \\
(0.023)\end{array}$ & $\begin{array}{c}0.018 \\
(0.026)\end{array}$ \\
\hline $2^{\text {nd }}$ Quartile National Reading Distribution & $\begin{array}{c}0.021 \\
(0.031)\end{array}$ & $\begin{array}{l}-0.000 \\
(0.031)\end{array}$ \\
\hline $3^{\text {rd }}$ Quartile National Reading Distribution & $\begin{array}{l}-0.022 \\
(0.036)\end{array}$ & $\begin{array}{l}-0.022 \\
(0.041)\end{array}$ \\
\hline $4^{\text {th }}$ Quartile National Reading Distribution & $\begin{array}{c}0.036 \\
(0.064)\end{array}$ & $\begin{array}{c}0.014 \\
(0.056)\end{array}$ \\
\hline \multicolumn{3}{|l|}{ Race, Gender \& SES } \\
\hline Black & $\begin{array}{l}-0.007 \\
(0.025)\end{array}$ & $\begin{array}{l}-0.004 \\
(0.029)\end{array}$ \\
\hline Hispanic & $\begin{array}{c}0.025 \\
(0.045)\end{array}$ & $\begin{array}{c}0.054 \\
(0.047)\end{array}$ \\
\hline White/Other & $\begin{array}{l}-0.287 \\
(0.149)\end{array}$ & $\begin{array}{l}-0.049 \\
(0.106)\end{array}$ \\
\hline Male & $\begin{array}{l}-0.026 \\
(0.023)\end{array}$ & $\begin{array}{c}0.009 \\
(0.026)\end{array}$ \\
\hline Female & $\begin{array}{c}0.009 \\
(0.027) \\
\end{array}$ & $\begin{array}{c}0.000 \\
(0.029)\end{array}$ \\
\hline Free Lunch & $\begin{array}{l}-0.009 \\
(0.022)\end{array}$ & $\begin{array}{c}0.008 \\
(0.026)\end{array}$ \\
\hline No Free Lunch & $\begin{array}{c}0.014 \\
(0.055)\end{array}$ & $\begin{array}{l}-0.011 \\
(0.046)\end{array}$ \\
\hline
\end{tabular}

Notes to Table 6: Sample includes students who were in schools in the Fall of 1996 that had between 5\% and $25 \%$ of students at or above national norms in reading. Also included (but not shown) in the regression specification are the controls described in Table 2. 
Table 7

Robustness Checks

\begin{tabular}{|c|c|c|c|c|c|}
\hline Row & Sample & $\begin{array}{c}\text { Dependent } \\
\text { Variable }\end{array}$ & Treatment & $\begin{array}{c}\text { Readin } \\
\text { g }\end{array}$ & Math \\
\hline & Original Estimates & & & & \\
\hline \multirow[t]{2}{*}{1} & $\begin{array}{l}\text { Baseline sample (students in } \\
1996 \text { schools where } 5-25 \% \\
\text { of students met national } \\
\text { norms in reading) }\end{array}$ & $\begin{array}{c}1999 \\
\text { Achievemen } \\
\mathrm{t}\end{array}$ & $\begin{array}{l}\text { Years in school on } \\
\text { probation }\end{array}$ & $\begin{array}{l}-0.007 \\
(0.022)\end{array}$ & $\begin{array}{c}0.005 \\
(0.026)\end{array}$ \\
\hline & $\begin{array}{c}\text { Alternative Samples \& } \\
\text { Specifications }\end{array}$ & & & & \\
\hline 2 & All schools & $\begin{array}{c}1999 \\
\text { Achievement }\end{array}$ & $\begin{array}{l}\text { Years in school on } \\
\text { probation }\end{array}$ & $\begin{array}{l}-0.012 \\
(0.013)\end{array}$ & $\begin{array}{l}-0.003 \\
(0.015)\end{array}$ \\
\hline 3 & $\begin{array}{l}\text { Baseline sample (controlling } \\
\text { for third order polynomials } \\
\text { of school performance) }\end{array}$ & $\begin{array}{c}1999 \\
\text { Achievement }\end{array}$ & $\begin{array}{l}\text { Years in school on } \\
\text { probation }\end{array}$ & $\begin{array}{l}-0.016 \\
(0.029)\end{array}$ & $\begin{array}{c}0.027 \\
(0.036)\end{array}$ \\
\hline 4 & $\begin{array}{l}\text { All schools }+ \text { cohort of } \\
\text { students in school in } 1993 \text { in } \\
\text { schools where } 5-25 \% \text { of } \\
\text { students met national norms } \\
\text { in reading }\end{array}$ & $\begin{array}{c}1999 \\
\text { Achievement }\end{array}$ & $\begin{array}{l}\text { Years in school on } \\
\text { probation }\end{array}$ & $\begin{array}{c}0.024 \\
(0.015)\end{array}$ & $\begin{array}{c}0.018 \\
(0.015)\end{array}$ \\
\hline 5 & $\begin{array}{l}\text { Baseline sample }+1993 \\
\text { cohort (all schools) }\end{array}$ & $\begin{array}{c}1999 \\
\text { Achievement }\end{array}$ & $\begin{array}{l}\text { Years in school on } \\
\text { probation }\end{array}$ & $\begin{array}{c}0.017 \\
(0.012)\end{array}$ & $\begin{array}{c}0.001 \\
(0.012)\end{array}$ \\
\hline 6 & $\begin{array}{l}\text { Baseline sample }+1993 \\
\text { cohort (controlling for } \\
\text { polynomials of school } \\
\text { performance) }\end{array}$ & $\begin{array}{c}1999 \\
\text { Achievement }\end{array}$ & $\begin{array}{l}\text { Years in school on } \\
\text { probation }\end{array}$ & $\begin{array}{c}0.030 \\
(0.016)\end{array}$ & $\begin{array}{c}0.019 \\
(0.014)\end{array}$ \\
\hline 7 & Baseline sample & $\begin{array}{c}1999 \\
\text { Achievement }\end{array}$ & $\begin{array}{l}\text { Years in school on } \\
\text { probation or } \\
\text { remediation }\end{array}$ & $\begin{array}{l}-0.004 \\
(0.029)\end{array}$ & $\begin{array}{c}0.011 \\
(0.034)\end{array}$ \\
\hline 8 & Baseline sample & $\begin{array}{c}1999 \\
\text { Achievement }\end{array}$ & $\begin{array}{l}\text { Years in school with } \\
\text { external partner }\end{array}$ & $\begin{array}{l}-0.003 \\
(0.027)\end{array}$ & $\begin{array}{c}0.011 \\
(0.032)\end{array}$ \\
\hline 9 & $\begin{array}{l}\text { Students in same school } \\
\text { from } 1996 \text { to } 1999\end{array}$ & $\begin{array}{c}1999 \\
\text { Achievement }\end{array}$ & $\begin{array}{l}\text { Years in school on } \\
\text { probation }\end{array}$ & $\begin{array}{l}-0.002 \\
(0.025)\end{array}$ & $\begin{array}{c}0.006 \\
(0.028)\end{array}$ \\
\hline 10 & Baseline sample & $\begin{array}{l}\text { 1998-1999 } \\
\text { Achievement } \\
\text { Gain }\end{array}$ & $\begin{array}{l}\text { Years in school on } \\
\text { probation }\end{array}$ & $\begin{array}{l}-0.035 \\
(0.018)\end{array}$ & $\begin{array}{l}-0.027 \\
(0.016)\end{array}$ \\
\hline 11 & $\begin{array}{l}\text { Students in same school } \\
\text { from } 1996 \text { to } 1999\end{array}$ & $\begin{array}{c}\text { 1998-1999 } \\
\text { Achievement } \\
\text { Gain } \\
\end{array}$ & $\begin{array}{l}\text { Years in school on } \\
\text { probation }\end{array}$ & $\begin{array}{l}-0.026 \\
(0.020)\end{array}$ & $\begin{array}{l}-0.019 \\
(0.017)\end{array}$ \\
\hline
\end{tabular}

Notes to Table 7: Baseline sample includes students who were in schools in the Fall of 1996 that had between 5\% and $25 \%$ of students at or above national norms in reading. Also included (but not shown) in the regression specification are the controls described in Table 2. All estimates are computed using two stage least squares. The instruments are as previously indicated except in the specifications in which the treatment is defined as years in school on probation or remediation and years in school with external partner. For these specifications, the instrument is a dummy variable indicating the school surpassed $15 \%$ at or above national norms in reading. 
Table 8

OLS Estimates of the Effect of Specific External Partners on Student Achievement

\begin{tabular}{l|c|c|}
\hline \multirow{1}{*}{ External Partner } & Treatment Effect of Year with External Partner on 1999 \\
Achievement & Math \\
\hline America's Choice-NARE & Reading & 0.020 \\
\hline Malcolm X College & 0.022 & $(0.031)$ \\
\hline School Achievement & $(0.031)$ & 0.017 \\
Structure & -0.001 & $(0.019)$ \\
\hline DePaul University & $(0.017)$ & 0.010 \\
& -0.001 & $(0.022)$ \\
\hline Northeastern Illinois & $(0.018)$ & -0.024 \\
University & 0.021 & $(0.024)$ \\
\hline North Central Regional & $(0.020)$ & 0.027 \\
\hline Other External Partner & 0.004 & $(0.024)$ \\
\hline F-Test of Joint Significance & $(0.025)$ & -0.038 \\
(P-value) & -0.019 & $(0.033)$ \\
Observations & $(0.024)$ & 0.027 \\
\hline Ning & 0.023 & $(0.023)$ \\
\hline
\end{tabular}

Notes to Table 8: The sample includes students who were in schools in the Fall of 1996 that had between 5\% and $25 \%$ of students at or above national norms in reading. We use all controls from the baseline (Table 2) specification as well as the total number of years a student was enrolled in a school on probation from 1997 to 1999. 